that its establishment is in some degree an epoch-making event in the development of the science of international law. The training it affords will equip its staff to render the highest character of service in the many spheres in which a sound and critical knowledge of international law and relations is essential. The integration of the Institute with the public service, and particularly with the activities of international tribunals, should aid the current evolution of the law. The aims and achievements of the Institute should furnish a goal and ideal for research organizations in other countries; and it may be hoped that in time its manifold labors will be shared by the coöperative effort of similar research institutes in other nations, and especially on the American Continent.

EDWIN M. Borchard.

\title{
HENRY G. CROCKER
}

We are so accustomed to associate greatness with outward achievement as to forget that it is an inherent, intrinsic quality and generally, although not always, brought to the surface by an outward incentive; and that often, especially if worldly ambition be lacking, the impelling cause to project itself from within must be very great indeed.

How then may we know the inherent qualities of those who have never expressed themselves, or at least not fully, to the outward world? By intercourse, by personal contact and an association which, little by little, discloses what does not show itself to the casual observer.

Alas for those that never sing,

But die with all their music in them!

Such was Henry G. Crocker-great in the qualities that make for greatness; great in the opinion of those who knew him well, and only lacking the ambition to have arrested the attention of the public which prefers to be shown, instead of discovering for itself, the inner light which burns with a consuming, although a hidden flame.

On the 5th day of June, 1930, the Carnegie Endowment for International Peace adopted, by its Executive Committee, the following resolution:

Henry Graham Crocker, a resident of Washington for over twentyeight years, died suddenly at Emergency Hospital on Tuesday, May 6, while convalescing from a minor operation.

Since January 1, 1914, Mr. Crocker was an assistant in the Division of International Law of the Carnegie Endowment for International Peace. He was an assistant legal adviser to the American Commission to Negotiate Peace at Paris in 1919, and was a member of the American representation that accompanied President Wilson on board the George Washington. He remained in Paris for over a year working upon the several peace treaties negotiated at that time.

Mr. Crocker's work was well known in the profession of international law, and he was the author of a compilation on the law of the marginal sea. He was a member of the American Society of International Law, 
and a corresponding member of the Societé de Législation Comparée of Paris.

Mr. Crocker was born in Milwaukee, Wisconsin, on August 10, 1868. He graduated from Yale Law School in 1892, and was a member of the Bars of Connecticut, Illinois and California. He was the principal of the Coronado High School from 1896 to 1900, and taught in a Los Angeles High School from 1900 to 1902 . He then came to Washington to enter the service of the Department of State, where he remained until he resigned to go with the Carnegie Endowment on January 1, 1914.

To this minute I would add Judge John Bassett Moore's appreciation:

"There has just been communicated to me the melancholy news, conveyed in your letter received this morning, of the passing away of Mr. Crocker. The length as well as the value of his service will cause his loss to be keenly felt, while the severance of old and cherished personal associations will create a profound sense of sorrow. I have known him since his first connection with the Endowment, and can speak advisedly as well as feelingly."

Lives such as Mr. Crocker's do not touch the world at large, but within a smaller circle they live in the lives of others; nobody who came into contact with him could forget the manner of man he was; no one could know him and not see what human nature could produce without apparent effort; and none could be taken into his life without being the better for it.

To live in the lives of others is not the least or the less enduring of that indefinable thing we call immortality.

JAMES Brown ScotT. 